\title{
The effect of job satisfaction and organizational commitment to employee retention in a lighting company
}

\author{
Andy Soenanta ${ }^{*}$, \\ Maruf Akbar ${ }^{1}$ \\ and \\ Rd. Tuty Sariwulan'1, \\ ${ }^{1}$ State University of Jakarta, \\ Jakarta, Indonesia \\ *Corresponding Author \\ Email: asoenantaunj@gmail.com
}

\begin{abstract}
Employee retention is a common issue in lighting companies due to its competitiveness of the industry. The objective of this research is to study the effect of the job satisfaction and organizational commitment to employee's retention in a lighting company. Quantitative approach used in this research with survey method. The sample size for this research were 204 employees selected randomly. The data were obtained by distributing questionnaire and analyzed by using path analysis. The result of the research can be concluded that: 1) job satisfaction and organizational commitment had a positive direct effect on employee's retention; 2) job satisfaction had a positive direct effect on organizational commitment. The implication is that weak or strong retention needs to be considered in company management because it will have an impact on the tendency or resilience of employee turnover.
\end{abstract}

Keywords: Job satisfaction, organizational commitment, employee retention

\section{INTRODUCTION}

Since the transition of incandescent and fluorescent to LED technology in the lighting industry, the lighting industry has become an open market with almost no barriers to entry. To win the tough competition, lamp manufacturers need to have a strong competitive advantage over their peers. In simple terms, competitive advantage can be defined as the ability obtained through the characteristics and resources of a company to have a higher performance than other companies in the same industry or market. According to Kotler and Keller (2012), competitive advantage or competitive advantage is an advantage over competitors obtained by offering lower value or by providing greater benefits due to higher prices.

Competitive advantage can be seen from several aspects such as capital, management, product quality, and distribution network. Competitive advantage to maintain product quality or distribution network that leads to customer loyalty depends on the ability of human resource management. Competence in Human Resource Management will lead to maximum utilization of other resources to achieve company profitability. To achieve company goals, it is necessary to pay attention to human resources, namely human resources that differentiate a company from other companies. Especially in an industry, where hundreds of similar players are playing with the same technology. Only people who have a competitive advantage can make the company win the competition with its competitors. Currently, the company faces a high employee turnover rate, which is above $10 \%$ for the last 5 years.

Employee retention is one of the main focuses in today's organizations (Oladapo, 2014). Employee retention is defined as the percentage of permanent employees in the organization (Phillips and Connell, 2004). In addition, employee retention is seen as an organizational strategy to keep human resources competitive (Long and Davenport, 2003). The main purpose of employee retention is to avoid losing competent employees which will have an impact on company productivity (Bansal, 2014).

Someone will judge whether they are satisfied or not with 
their work. The level of satisfaction can be high or low depending on the aspects received from the workplace. Luthans (2011) suggests that when someone gets job satisfaction from their work environment, they will give good performance, and vice versa. In line with that, some experts argue that job satisfaction is a positive feeling towards work, whereas dissatisfaction is a response to negative feelings about work and / or the workplace (Robbins, 2006; Vecchio, 1995; Wibowo, 2007). Kirkpatrick and Levis (1996) states that job satisfaction is a person's attitude towards elements of the nature of the job itself, relationships with colleagues, compensation received, promotion opportunities, quality of supervision received and work situations.

Organizational commitment is defined as the desire on the part of an employee to remain a member of the organization (Mayer and Natalie, 1997). According to Robbins (2006), organizational commitment is the extent to which an employee identifies with the organization and specific goals and the desire to maintain membership in the organization. The same opinion was also expressed by Colquitt et al. (2015), Luthans (2011), Mowday (1998), Schermerhorn, James, and Richard (2010), Gibson, Ivancevich, and Konopaske (2015), and Cooper (2011) which in essence concluded, organizational commitment is a condition in which large an employee commits himself to the organization and adheres to organizational goals, and hopes to retain membership in the organization.

Mayer and Natalie (1997); Cooper (2011); Colquitt et al. (2015) divide organizational commitment into 3 types, namely: affective commitment, continuous commitment, and normative commitment. Affective commitment refers to the emotional aspects of employees regarding their involvement in an organization. Employees who have a strong affective commitment tend to be loyal to the company. However, this is also determined by the level of income, job satisfaction, and career certainty of employees in the company which emotionally creates a pleasant and comfortable situation, or vice versa. Continuous commitment refers to the employee's view of work in the company that encourages morale, hope, and the desire to stay or leave the company. Employees consider sustainability in the company because of their need for the company, on the other hand, leaving the company will cause losses. The strength of continuity commitment tends to bring someone to continue working in a company. Normative commitment is the employee's feelings about the obligations that must be given to the organization based on certain norms and rules. The commitment of employees to continue working for the organization due to pressure from these norms and rules, including working time, work discipline, and a reward system for work performance. This commitment refers to a reflection of the feeling of his rights and obligations as an employee of the company. Dwiarta (2010) concluded that strong normative commitment will be formed if employees are able to internalize norms and rules regarding work obligations, are applied consistently and consequently, and are considered useful in meeting their needs.

Higher employee retention will provide benefits for the company such as higher productivity, maximum profitability and reduced costs. High employee retention in an organization can result from the opportunities given to employees to develop professionalism which will lead to higher and long-term loyalty to the company (Silvia, 2013). It is expected that better job satisfaction and higher organizational commitment will increase employee retention.

This study aims to get a better understanding with the title "The Effect of Job Satisfaction and Organizational Commitment on Employee Retention in Lighting Companies". The identification of problems in this study are: 1) Is there an effect of job satisfaction on employee retention. 2) If there is an effect of organizational commitment on employee retention. 3) If there is a direct effect of job satisfaction on organizational commitment. The results of the study are expected to provide more understanding of the effect of job satisfaction and organizational commitment on employee retention, so that these two factors will receive consideration from the company in managing human resources for business progress.

\section{METHODOLOGY}

This research uses a quantitative approach, with a survey form through a causal approach. The survey results were analyzed using multivariate statistics with path analysis. This research is a case study in a lighting company with 383 employees. From the employee population, a sample of 204 employees was taken based on the Slovin formula.

Data collection in this study was carried out by distributing questionnaires designed in the form of a Likert scale. In this scale the questions are equipped with five alternative answers and their weight for each alternative. For the Linkert scale, the details are as follows: Always $=5$, Often $=4$, Sometimes $=3$, Rarely $=2$ and Never $=1$. This study uses 3 instruments to measure employee retention, job design and organizational commitment. The instrument has been tested on 30 respondents, to obtain valid and reliable instrument points using Pearson and Cronbach Alpha criteria.

The analysis technique is path analysis. Prior to the analysis, several test requirements must be met, namely: data normality test, linearity test and regression significant test.

\section{RESULTS}

\section{Respondent Characteristics}

The study respondents consisted of $56(76.5 \%)$ male and $48(23.5 \%)$ female. most of them are married with the number of families ranging from $4-6$ people. As many as 
Table 1. Answers to the Level of Satisfaction, Organizational Commitment, and Employee Retention of Light Companies ( $\mathrm{N}=204)$

\begin{tabular}{|c|c|c|c|c|c|c|}
\hline No. & Statement & 1 & 2 & 3 & 4 & 5 \\
\hline $\mathbf{A}$ & Job Satisfaction & & & & & \\
\hline 1. & $\begin{array}{l}\text { Payroll at this company is in accordance with } \\
\text { the rules }\end{array}$ & $15(7.4)$ & 25 (12.3) & $40(19.5)$ & $30(14.8)$ & $94(46.0)$ \\
\hline 2. & $\begin{array}{l}\text { There is health insurance for employees and } \\
\text { their families in the company }\end{array}$ & $5(4.5)$ & $10(9.0)$ & $7(6.3)$ & $42(20.5)$ & $140(68.70$ \\
\hline 3. & $\begin{array}{l}\text { There is a bonus every year that employees } \\
\text { receive from the company. }\end{array}$ & $22(10.8)$ & $20(18.0)$ & $12(10.9)$ & 95 (86.3) & $55(50.0)$ \\
\hline 4. & $\begin{array}{l}\text { Employees receive a large religious day } \\
\text { allowance. }\end{array}$ & $-(0.00)$ & $-(0.00)$ & $16(7.8)$ & $162(79.4)$ & $26(12.7)$ \\
\hline 5. & $\begin{array}{l}\text { There are annual leave entitlements for } \\
\text { employees }\end{array}$ & $10(9,0)$ & 28 (13.7) & $20(18,0)$ & $132(64.7)$ & $14(6,6)$ \\
\hline 6. & $\begin{array}{l}\text { I am quite loyal to the company because I apply } \\
\text { the rules consistently and consistently. }\end{array}$ & $24(11.7)$ & $36(17.6)$ & $18(8.8)$ & $98(48.0)$ & 28 (13.7) \\
\hline 7. & $\begin{array}{l}\text { In this company has a clear career } \\
\text { development. }\end{array}$ & $45(22.0)$ & $33(16.2)$ & 25 (12.3) & $62(30.4)$ & 39 (19.1) \\
\hline 8. & $\begin{array}{l}\text { I will continue to work at this company, even } \\
\text { though there are job opportunities with better } \\
\text { income. }\end{array}$ & $10(9.0)$ & $17(8.3)$ & 85 (41.7) & $58(28.4)$ & $34(16.6)$ \\
\hline 9. & $\begin{array}{l}\text { There are clear rules regarding the increase in } \\
\text { salaries / wages of employees. }\end{array}$ & $36(17.6)$ & 24 (11.7) & $30(14.7)$ & $70(34.3)$ & 44 (21.7) \\
\hline 10. & $\begin{array}{l}\text { In the company there is a reward system for } \\
\text { employees who excel. }\end{array}$ & $32(15.7)$ & $26(12.7)$ & 44 (21.7) & 65 (31.8) & 37 (18.1) \\
\hline & Average & $29.4(14.4)$ & $27.2(13.3)$ & $40.4(19.8)$ & $70.6(34.6)$ & $36.4(17.8)$ \\
\hline C. & Employe & & & & & \\
\hline 11. & $\begin{array}{l}\text { The company pays attention to placement in } \\
\text { accordance with the knowledge and abilities } \\
\text { possessed by employees. }\end{array}$ & $47(23.0)$ & 38 (18.6) & $22(10.8)$ & $60(29.4)$ & 37 (18.2) \\
\hline 12. & $\begin{array}{l}\text { The company manages the workplace as } \\
\text { comfortable as possible for employees. }\end{array}$ & 38 (18.6) & $36(17.6)$ & $45(22.0)$ & $55(50.0)$ & 30 (14.8) \\
\hline 13. & $\begin{array}{l}\text { Company leaders strive to create a harmonious } \\
\text { and mutually supportive working relationship } \\
\text { between employees. }\end{array}$ & 35 (17.2) & 28 (13.7) & 38 (18.6) & $70(34.3)$ & 33 (16.2) \\
\hline 14. & $\begin{array}{l}\text { Employee performance is evaluated by the } \\
\text { company to determine career paths. }\end{array}$ & $16(7.8)$ & $18(8.8)$ & $10(9.0)$ & 105 (51.5) & $55(50.0)$ \\
\hline \multirow[t]{3}{*}{15.} & $\begin{array}{l}\text { Each year there is time for employees to take } \\
\text { recreation together. }\end{array}$ & $65(31,8)$ & 32 (15.7) & $15(7.4)$ & $80(39.2)$ & $12(10.9)$ \\
\hline & & 4( & & & & 33 \\
\hline & Total Average & $26.7(13.0)$ & $24.7(12.2)$ & $28.5(14.0)$ & $78.9(38.6)$ & $45.2(22.2)$ \\
\hline
\end{tabular}

$88.2 \%$ of employees have worked for more than 5 (five) years while $11.8 \%$ have only worked between 1 year - 4 years. Income levels vary from the regional minimum wage criteria of IDR 4.2 million for contract workers, to IDR 40 million for middle managers. Table 1 below presents respondents' answers about the level of satisfaction, organization and retention of employees in the workplace.

Table 1 shows that on average the majority (77.4\%) of the employees studied showed a level of satisfaction with the workplace, especially regarding salaries, health insurance, annual allowances, allowances for major religious celebrations (Ied Fitri, Christmas, etc.) , and the existence of leave rights for employees, especially for female employees who give birth. More than half of employees (52.4\%) also tend to support strong organizational commitment, because the company is considered to have implemented consistent and consistent (normative) rules, managed employees according to their talents and created resilience by building harmonious and mutually supportive working relationships. continuity of work, as well as increasing salaries in accordance with regulations and implementing a reward system for employees who excel (affective). A small proportion of employees $(27.7 \%)$ tended to have low commitment, especially for employees at lower levels and had contract status. Even though the company has applied a salary above the regional minimum wage, because it is not clear how they will be appointed as permanent employees, they are ready to move when the work contract expires.

It is suspected that job satisfaction and organizational commitment affect the retention of the employees studied. In Table 1, it can be seen that half of the employees tend to 
Table 2. Summary of Galat Estimation Normality Test with Liliefors Test (Lo)

\begin{tabular}{lccc}
\hline Galat Estimation Regression & L Count & Ltable $\alpha=0.05$ & \\
\hline Y to $X_{1}$ & 0.037 & 0.062 & Normal \\
$Y$ to $X_{2}$ & 0.049 & 0.062 & Normal \\
$X_{2}$ to $X_{1}$ & 0.03 & 0.062 & Normal \\
\hline
\end{tabular}

Note: $L$ table $=\alpha=0.05=0.886 / \sqrt{n}$

Table 3. Summary of Regression Linearity Test Result

\begin{tabular}{|c|c|c|c|c|c|}
\hline \multirow{3}{*}{ Variable } & \multirow{3}{*}{ Equity } & \multicolumn{3}{|c|}{ Linearity Test } & \\
\hline & & \multirow[t]{2}{*}{$\mathbf{F}_{\text {count }}$} & \multicolumn{2}{|c|}{$F_{\text {table }}$} & \\
\hline & & & $\alpha=0.05$ & $\alpha=0.01$ & \\
\hline \multirow{2}{*}{$\mathrm{Y}$ to $\mathrm{X}_{1}$} & \multirow{2}{*}{$\hat{\mathrm{Y}}=68.603+0.450 \mathrm{X}_{1}$} & 143.537 & 3.89 & 6.76 & \multirow{2}{*}{ Significant and Linear } \\
\hline & & 0.992 & 1.40 & 1.61 & \\
\hline \multirow{2}{*}{$\mathrm{Y}$ to $\mathrm{X}_{2}$} & \multirow{2}{*}{$\hat{Y}=1.452+0.695 X_{2}$} & 402,309 & 3.89 & 6.76 & \multirow{2}{*}{ Significant and Linear } \\
\hline & & 1.355 & 1.40 & 1.61 & \\
\hline $\mathrm{X}_{2}$ to $\mathrm{X}_{1}$ & $X_{2}=45.663+0.579 X_{1}$ & 84.740 & 3.90 & 6.80 & Significant and Linear \\
\hline
\end{tabular}

support strong retention, especially in relation to the treatment of companies that pay attention to the knowledge and abilities of employees in job placement, giving employees a sense of comfort. employee workplace, leadership support for harmonious working relationships, and so on. How much influence do job satisfaction and organizational commitment have on employee retention will be analyzed statistically below.

\section{Requirements Analysis}

Research variable description which consist of job design, organizational commitment, and employee retention, is prepared in a statistic description which include minimum score, maximum score, range, mean, modus, median, standard deviation, and variants.

Analysis requirement test which is used in the research including normality test, linearity test, and regression significant test. Normality test in this research use Galat data estimation. By using Lifefors test, so data is normal if $\mathrm{L}$ count $<\mathrm{L}$ table, and data is not normal if $\mathrm{L}_{\text {count }}>\mathrm{L}_{\text {table. }}$ Summary of normality test calculation result for each Galat estimation is as follow:

Meanwhile, for regression significant test using Variant Analysis (ANAVA), if $F_{\text {count }}>F_{\text {table }}$ with error level $(\alpha) 0,05$, then regression equity is significant and with error level $(\alpha)$ 0,01 , then equity is very significant. The result of regression significant test for job design, organizational commitment and employee retention is shown in Table 2 and Table 3 as follow:

\section{Hypothesis Testing}

To test hypothesis research, structural equation is divided into:

Substructural Equation 1:

Result of coefficient path calculation, there is a direct effect of job design and organizational commitment to employee retention.

$$
\begin{aligned}
& Y=P_{\mathrm{y} 1} \mathrm{X}_{1}+\mathrm{P}_{\mathrm{y} 2} \mathrm{X}_{2} \ldots \ldots \ldots . . . . . \\
& \mathrm{Y}=0.255 \mathrm{X}_{1}+0.565 \mathrm{X}_{2}
\end{aligned}
$$

Substructural Equation 2:

Result of coefficient path calculation, there is a direct effect of job design to organization commitment.

$$
\begin{aligned}
& X_{2}=P_{21} X_{1} \ldots \\
& X_{2}=0.378 X_{1}
\end{aligned}
$$

Path coefficient and value $t$ count can be seen from below path Figure 1:

The results in Figure 1 show that the theoretical model tested represents or is in line with the equation structure based on empirical data. The results of this study are in line with the existing theory in which job satisfaction and organizational commitment have a positive influence on employee retention.

One particular emphasis is that organizational commitment has a greater influence than job satisfaction, so it can be interpreted that the strength or weakness of retention is determined by this organizational commitment, both from the normative, continuity, and affective side. However, this retention cannot ignore the effect of employee job satisfaction.

This of course implies from a practical point of view that every company must pay attention to this aspect of organizational commitment by paying attention to and increasing awareness, attitudes and behavior of employees towards retention commitment, which directly determines the progress of the company. This commitment also contains job satisfaction which can determine whether an employee is likely to continue his work, or has strong or weak retention which determines employee loyalty to 


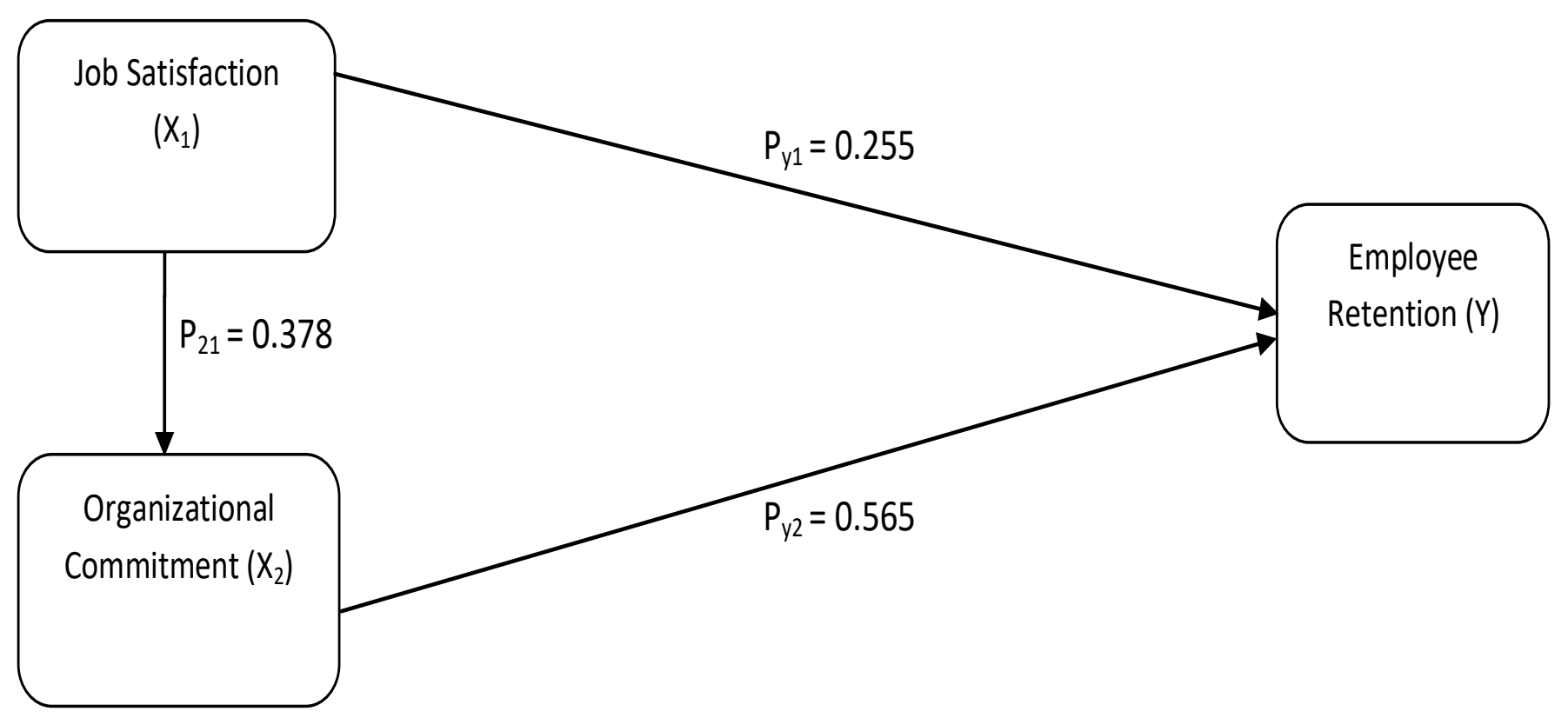

Figure 1: Path coefficient and $t_{\text {count }}$ job satisfaction, and organizational commitment to employee retention at lighting company

the company.

\section{DISCUSSION}

Based on the results of hypothesis testing, job satisfaction and organizational commitment have a positive and significant direct effect on employee retention. These findings provide empirical evidence that better job satisfaction and employee organizational commitment will provide higher employee retention. This finding is consistent with the findings of research conducted by Lambert and Paoline (2008) which states that 'employees who are dissatisfied or not committed to their work tend to quit voluntarily'. Job satisfaction and organizational commitment are seen as significant factors affecting employee retention. Biason (2017) states that job satisfaction and organizational commitment are what employees are looking for and are key elements of employee retention that can occur if employees feel comfortable both physically and emotionally.

These findings indicate that empirically job satisfaction and high organizational commitment from employees will increase employee retention. Companies should pay attention to job satisfaction and employee organizational commitment to increase retention and company progress. Both variables tend to develop employee loyalty so that it has a positive impact on higher business performance in terms of increased sales, productivity, profitability, and higher employee retention (Rogers, 2001; Tsui et al, 1995).

In addition, the strategy of increasing commitment will shape the behavior and attitudes of employees needed to build a psychological relationship between the organization and company goals. So companies need to focus on developing employee commitment that can be trusted in carrying out their duties consistently in supporting organizational goals (Eisenhardt, 1985).

Hypothesis testing also proves that job satisfaction has a positive and significant effect on organizational commitment. These findings indicate that empirically good job satisfaction will increase organizational commitment. This fact helps explain how important job satisfaction is in increasing organizational commitment. The results of research by Deepak et al. (2018) show that there is a significant relationship between job satisfaction and organizational commitment. These findings indicate employee recognition of job satisfaction with their work space in a green building.

Various studies have also shown that employee dissatisfaction with their work often leads to work stress attitudes, leading to a low level of employee commitment to work organizations. The latter situation not only leads to low work productivity, but also low loyalty, and a strong desire to resign from work (Aghdasi et al., 2011; Abolghasem et al., 2015; Velnampy and Aravinthan, 2013; Tahir, 2010; Gill et al., 2010; George, 2013; Sariwulan et al., 2019).

\section{CONCLUSION}

The results of the study reinforce the theory that Job Satisfaction has a positive direct effect on employee retention; Organizational commitment has a direct positive 
effect on employee retention; Job satisfaction has a direct positive effect on organizational commitment. This strengthening at the same time shows that these variables are determinants of the company's progress, so it needs serious attention. Employees who feel dissatisfied with the workplace, will affect the strength or weakness of commitment to the work organization, which in turn affects the strength and weakness of employee retention.

\section{Recommendation}

Based on the research results, the following suggestions are made.

Retaining good prospective employees with the right placement tends to shape employee job satisfaction. High job satisfaction, not only from a monetary point of view (adequate salary) but also a challenge for prospective employees to excel and be appreciated by the company.

Remuneration is not the only way for better talent management. There are many other factors that can increase employee retention, one of which is organizational commitment. However, organizational commitment is also influenced by leadership attitudes, job satisfaction, consistent and consistent application of rules, appreciation for achievement, and so on, which need to be considered by companies to develop strong employee retention.

For further research with other disciplines, it will be useful for any organization if they can easily monitor the retention factors of its employees, so that every decision the organization makes can be calculated not only from profitability but also from increasing its employees.

\section{Conflict of interests}

The authors declare that they have no conflict of interests.

\section{REFERENCES}

Abolghasem M (2015) Effects of Stresss on Auditor Organizational Commitment, Job Satisfaction, and Job Performance, Int. J. Organizational Leadership, 4:303-314.

Aghdasi S, Ali RK, Abdolrahim NE (2011). Emotional Intelligence and Organizational Commitment: Testing the Mediatory Role of Occupational Stress and Job Satisfaction. Procedia Soc. Behavioral Sci. 29:1965 - 1976.

Biason RS (2017). The effect of Job Satisfaction to Employee Retention. J. Bus. Management Rev., 1 (April 2017), 1-10

Cooper DJ (2011). Leadership for Follower Commitment, New York: Routledge.

Colquitt JA, Jeffery AL, Michael JW (2015). Organizational Behavior Improving Performance and Commitmen in the Workplace, New York: McGraw Hill/Irwin.

Deepak B, Prakash T, Pankaj C (2018). Workplace Design Features, Job Satisfaction, and Organization Commitment. J. workplace rights, July-September 2017: 1 -12

Eisenhardt KM (1985). Control: organisational and economic approaches. Management Science, 31:134-149
Dwiarta MB (2010). Analysis of Job Characteristics and Promotional Opportunities Against Intention to Quit Through Job Satisfaction and Employee Commitment in Three and Four Star Hotels in Surabaya. Surabaya: Airlangga University.

George R (2013) The Effect of Leadership Style on Work Stress Related Presenteeism, University of Pretoria.

Gibson J, Ivancevich J, Konopaske R (2015) Organizations Behavior Structure Processes. Fourteenth Edition. New York: McGraw-Hill Companies, Inc.

Gill A, Flaschner AB, Bhutani S (2010) The Impact of Transformational Leadership and Empowerment on Employee Job Stress, Bus. Econ. J. 3:1 - 11.

Kirkpatrick TO, Levis CT (1995). Effective Supervision, New York: The Bryden Press.

Kotler P, Keller KL (2012). Marketing Management, Singapore: Prentice Hall.

Lambert EG, Paoline EA (2008). The Influence of Individual, Job, and Organizational Characteristics on Correctional Staff Job Stress, Job Satisfaction and Organizational Commitment. Criminal Justice Review, 33(4):541-564.

Long D, Davenport T (2003). Better practices for retaining organizational knowledge: Lessons from the leading edge. Employment Relations Today, 30:51-63.

Luthans F (2011). Organizational Behavior. New York: McGraw-Hill.

Meyer JP, Natalie JA (2002). Commitment in the Worplace Theory Research and Application. California: Sage Publications.

Oladapo V (2014). Impact of talent management on retention. Journal of Business studies, 5(3).

Phillips JJ, Connell AO (2004). Managing Employee Retention. Burlington, MA: Elsevier

Robbins SP (2006). Essentials of Organization Behavior, New Jersey: Prentice-Hall International Inc.

Rogers EW (2001). A theoretical look at firm performance in high technology organisations: What does existing theory tell us? J. High Technol. Manag. Res., 12:39-61.

Sariwulan T, Agung I, Capnary MC (2019). Contributions of Indicator to Work Stress Toward and Employee Organizational Commitments: Case Study, J. Bus. Theory and Practice, 20:293 - 302 .

Schermrhorn JR Jr., James GH, Richard NO (2010) Organizational Behavior. New York: John Wiley \& Sons, Inc.

Silvia K (2013). Relationship between Talent Management and Employee Retention in Commercial Banks of Kenya. Research Project Submitted in Partial Fulfilment of the Requirement for the Award of the Degree of Master of Business Administration (MBA), School of Business, University of Nairobi. Thakur, 2015.

Tahir S (2010). The Impacts of Employees Job Stresss on Organizational Commitment, European J. Soc. Sci.,. 13 (4).

Tsui AS, Pearce JL, Porter LW, Hite JP (1995). Choice of employee-organisation relationship: Influence of external and internal organisational factors, in G. R. Ferris (ed.) Research in personnel and human resources management (pp. 117-151). Greenwich, CT: JAI. 
Vecchio RP (1995). Organizational Behavior, Florida: The Dryden Press.

Velnampy T, Aravinthan SA (2013) Occupational Stresss and Organizational Commitment in Private Banks: A Sri Lankan Experience. European J. Bus. Manag. 5(7):1905 1917.

Wibowo (2007). Performance Management, Jakarta: RajaGrafindo. 